\title{
Experience with the systemic treatment of severe forms of psoriasis
}

\author{
Martin Tichy', Jana Zapletalovab
}

\begin{abstract}
Introduction. Severe forms of psoriasis are indicated for systemic treatment with conventional and biological preparations. The former includes methotrexate, cyclosporin, acitretin and narrow-band ultraviolet B phototherapy but toxicity may limit the dose and duration of treatment. Currently used less toxic biological preparations include inhibitors of TNF-alpha (etanercept, adalimumab, infliximab) and the monoclonal antibody against IL 12/23 ustekinumab. We present our own more than five-year experience with the systemic treatment of severe forms of psoriasis using these preparations.

Methods. A total of 66 patients treated with systemic therapy (except for phototherapy) were divided into groups based on treatment. Therapeutic doses were administered according to the recommendations of the manufacturer and dermatological societies. Standard PASI and BSA indexes were used to evaluate clinical condition at weeks 0, 12 and 24. Results. Differences in PASI score reduction and BSA index between patient groups treated with different preparations were statistically significant at monitored intervals. At week 12 , PASI score was reduced by $75 \%$ or more in a significantly greater number of patients treated with infliximab + methotrexate than those treated with acitretin. At week 24 , identical comparison showed a significantly greater number of patients treated with etanercept or adalimumab than those receiving methotrexate. For BSA index reduction by $50 \%$ or more, no statistically significant differences were found between patient groups during the follow-up period.

Conclusion. Systemic therapy provides a significant benefit to patients with severe psoriasis. Biological preparations are more effective than conventional medications which are often limited by severe side-effects and generally less tolerated than biological treatments.
\end{abstract}

Key words: psoriasis, systemic therapy, conventional therapy, biological therapy, adalimumab, etanercept, infliximab, ustekinumab

Received: August 15, 2011; Accepted with revision: January 4, 2012; Available online: January 30, 2012 http://dx.doi.org/10.5507/bp.2012.007

${ }^{a}$ Department of Dermatology and Venereology, Faculty of Medicine and Dentistry, Palacky University Olomouc, Czech Republic ${ }^{b}$ Department of Medical Biophysics, Faculty of Medicine and Dentistry, Palacky University Olomouc Corresponding autor: Martin Tichý, e-mail: tichy.martin.jun@fnol.cz

\section{INTRODUCTION}

Recent research progress in the pathogenesis of psoriasis has led to entirely new therapeutic procedures, especially in the treatment of severe forms which fail to respond to conventional treatments. The latter include phototherapy and the oral prescription medications methotrexate (MTX), acitretin and cyclosporin. Preparations currently used in the treatment of immune-mediated disorders like psoriasis, include the so-called biologicals. These are biotechnologically formulated drugs intended for systemic application and in terms of their mechanism of action, they can be included as selective immunosuppressants ${ }^{1,2}$. A number of biological preparations have already successfully been used in the treatment of immune-mediated diseases, including psoriasis. At present, four are available in the Czech Republic. These work by inhibiting the action of certain pro-inflammatory cytokines which play a significant role in the pathogenesis of psoriatic inflammation ${ }^{3,4}$. Three are inhibitors of TNF-alpha (tumor necrosis factor) - etanercept, adalimumab, infliximab. Etanercept is a soluble dimeric protein formed by the fusion of the extracellular TNF alpha p75 domain with the Fc part of human IgG1. Its mechanism of action is based on competitive inhibition of TNF alpha by binding to its cell surface receptors and weakening its pro-inflammatory effect ${ }^{2,3,5}$. Adalimumab is a recombinant, fully human anti-TNF alpha specific monoclonal IgG1 antibody while infliximab is a chimeric human (75\%) antibody with mouse component (25\%). The mechanism of action of both preparations is similar. The binding of monoclonal antibodies to TNF alpha creates stable complexes, which bind complement, and as such induce apoptosis and subsequent lysis of cells producing TNF alpha and granuloma degradation ${ }^{2,3,6,7}$.

The last, ustekinumab, is a monoclonal antibody against IL $12 / 23$. It has a strong binding affinity to protein $\mathrm{p} 40$, which is a subunit of interleukins 12 and 23. It inhibits the binding of these two cytokines which are significant in the pathogenesis of psoriasis, to their receptor protein IL-12R beta and inhibits the cytokine cascade ${ }^{4,8}$.

Indications for the use of biologics in the treatment of psoriasis are governed by the "Guidelines of the Czech Dermatological Society", as well as by updated versions of guidelines published by other major national societies ${ }^{9-14}$. 


\section{OBJECTIVES}

To present our own experience with the systemic treatment of patients with severe forms of psoriasis between 2005 and 2010 at a specialised Counseling Centre of the Department of Dermatology and Venereology. The focus was primarily on comparing the effectiveness of individual therapeutic methods as well as their safety/side effects.

\section{METHODS}

A sample of 66 patients $48(72.7 \%)$ men and 18 (27.3\%) women, average age of the men 45.3 years, women 45.8 years with severe forms of psoriasis resistant to topical therapy and phototherapy were followed and treated with the above methods of systemic therapy (excluding phototherapy) over the 5-year interval. The patients were divided into groups based on treatment received (Table 1). If several therapeutic methods were used over time in one patient, the patient was included in more than one group. Patients who received combined systemic therapy were registered in a separate group. Therapeutic doses were based on the guidelines of the manufacturer and of dermatological societies ${ }^{9-14}$ (Table 2).

The largest group was represented by patients treated with etanercept, the smallest group were patients treated with ustekinumab.

The average age differences between the individual groups was not significant (Kruskal-Wallis test, $P=0.511$ ). Similarly differences in the distribution of treated women and men in the individual groups were not significant (Fischer's exact test, $P=0.77$ ).

Severe psoriasis was defined by generally used evaluation criteria for extent of chronic plaque psoriasis and intensity of involvement measured by standard BSA (Body
Table 1. Distribution of patients based on therapy received.

\begin{tabular}{l|l|l}
\hline Medication & Frequency & Percent \\
\hline Cyclosporin & 13 & 13.1 \\
Etanercept + MTX & 4 & 4.0 \\
Etanercept & 29 & 29.3 \\
Adalimumab & 11 & 11.1 \\
MTX & 17 & 17.2 \\
Acitretin & 13 & 13.1 \\
Infliximab+MTX & 8 & 8.1 \\
Ustekinumab & 4 & 4.0 \\
\hline
\end{tabular}

Surface Area) and PASI (Psoriasis Area Severity Index) indexes, whose values in the treated patients were greater or equal to 10 . In the sample of tested patients, topical therapy and phototherapy were ineffective, or despite temporary improvement early recurrence was observed. Based on age, gender and concomitant diseases, one of the conventional treatments was indicated. Biological therapy was administered immediately without prior conventional therapy in 5 patients where standard drugs were contraindicated (severe liver disease, poorly compensated hypertension). In cases where conventional preparations proved ineffective or where side effects occurred, patients were transferred to an alternative systemic therapy. Indications for administering biological therapy were based on valid criteria established by the Czech Dermatology Society ${ }^{9}$. Biological treatment was indicated in patients where at least two standard systemic treatments proved ineffective or in patients where conventional treatment was contraindicated.

Table 2. Recommended dosage of conventional and biological drugs using for the treatment of psoriasis.

\begin{tabular}{|c|c|c|}
\hline Medication & Recommended initial dosage & Recommended maintenance dosage \\
\hline Methotrexate & 5-10mg weekly & 5-30mg weekly (orally, s.c., i.m.) \\
\hline Cyclosporin A & 2.5-3 (max. 5) mg/kg daily & $\begin{array}{l}\text { Interval therapy - at the end of induction therapy } \\
\text { (e.g. } 0.5 \mathrm{mg} / \mathrm{kg} \text { every } 14 \text { days) or } \\
\text { continuous long - term therapy }(0.5-3 \mathrm{mg} / \mathrm{kg} \text { daily), } \\
\text { in case of relaps dosage increase } \\
\text { maximum total duration of therapy: } 2 \text { years }\end{array}$ \\
\hline Acitretin & $\begin{array}{l}0.3-0.5 \mathrm{mg} / \mathrm{kg} \text { daily for } 4 \text { weeks } \\
\text { then } 0.5-0.8 \mathrm{mg} / \mathrm{kg} \text { daily }\end{array}$ & $\begin{array}{l}\text { individual dose dependent on response and toler- } \\
\text { ance }\end{array}$ \\
\hline
\end{tabular}

$\begin{array}{ll}\text { Adalimumab } & 80 \mathrm{mg} \text { s.c. at week } 0 \\ \text { Etanercept } & \begin{array}{l}2 \times 25 \mathrm{mg} \text { or } 2 \times 50 \mathrm{mg} \text { s.c. weekly } \\ (\text { weeks } 0-12)\end{array} \\ \text { Infliximab } & 5 \mathrm{mg} / \mathrm{kg} \text { body weight i.v. }\end{array}$

Ustekinumab $\quad 45 \mathrm{mg}$ s.c. or $90 \mathrm{mg}$ s.c. (patients weighing > $100 \mathrm{~kg}$ ) at week 0
$40 \mathrm{mg}$ s.c. every other week

$2 \times 25 \mathrm{mg}$ or $1 \times 50 \mathrm{mg}$ s.c. weekly

$5 \mathrm{mg} / \mathrm{kg}$ body weight i.v. 2, 6 and every 8 weeks thereafter

$45 \mathrm{mg}$ s.c. or $90 \mathrm{mg}$ s.c. at 4 and every 12 weeks thereafter 
Table 3. Decrease in PASI and BSA values in percentages.

\begin{tabular}{llrrrr}
\hline \multirow{2}{*}{ Medication } & PASI decrease & $\begin{array}{c}\text { PASI } \\
\text { at week } 12\end{array}$ & $\begin{array}{r}\text { decrease at } \\
\text { week } 24\end{array}$ & $\begin{array}{c}\text { BSA decrease } \\
\text { at week 12 }\end{array}$ & $\begin{array}{c}\text { BSA decrease } \\
\text { at week } 24\end{array}$ \\
\hline Cyclosporin & N & 12 & 9 & 12 & 9 \\
& Maximum & -93.3 & -82.1 & -100.0 & -94.7 \\
& Median & -37.5 & -20.7 & .0 & -40.4 \\
& Mean & -75.6 & -67.3 & -81.0 & -76.0 \\
& Std. Deviation & -73.7 & -65.1 & -73.7 & -69.5 \\
\hline Etanercept+MTX & 15.7 & 18.1 & 27.0 & 18.4 \\
& N & 4 & 4 & 4 & 4 \\
& Minimum & -71.4 & -90.0 & -82.4 & -88.2 \\
& Maximum & -17.6 & 23.5 & 25.0 & 50.0 \\
& Median & -41.3 & -39.7 & -40.5 & -44.1 \\
& Mean & -42.9 & -36.5 & -34.6 & -31.6 \\
& Std. Deviation & 28.0 & 59.8 & 51.6 & 64.9 \\
\hline Etanercept & N & 28 & 28 & 29 & 28 \\
& Minimum & -100.0 & -100.0 & -100.0 & -100.0 \\
& Maximum & .0 & -23.5 & .0 & -20.0 \\
& Median & -57.1 & -84.8 & -47.8 & -87.4 \\
& Mean & -63.1 & -79.9 & -54.5 & -79.4 \\
& Std. Deviation & 20.3 & 19.6 & 27.2 & 23.6 \\
\hline Adalimumab & N & 9 & 7 & 9 & 7 \\
& Minimum & -100.0 & -100.0 & -100.0 & -100.0 \\
& Maximum & 5.6 & -80.0 & .0 & -86.7 \\
& Median & -76.9 & -100.0 & -82.6 & -100.0 \\
& Mean & -69.8 & -93.6 & -74.4 & -95.8 \\
& Std. Deviation & 31.1 & 8.7 & 30.4 & 5.5 \\
\hline
\end{tabular}

Report - decrease in \%

Standard PASI (Psoriasis Area Severity Index) and BSA (Body Surface Area) indexes were used in weeks $0,12,24$ for evaluation of clinical findings ${ }^{15-17}$. The data were statistically analysed using SPSS software version 15 (SPSS Inc., Chicago, USA). The categorical parameters were compared using Fisher's exact test. With respect to the abnormal distribution and/or small number of patients in some groups, the Kruskal-Wallis test was used to compare quantitative parameters. In case of significant results of Kruskal-Wallis test, Mann-Whitney test with Bonferroni correction of significance was used to compare pairs of groups. Bonferroni correction was used for multiple comparisons to reduce the risk of type one error to $5 \%$. Normality of data was verified using the Shapiro-Wilk test. The significance level was 0.05 .

\section{RESULTS}

The average decrease in PASI score in weeks 12. and 24. in individual groups expressed in percentages is shown in Table 3, 4.
The average decrease in PASI score at week 12 and at week 24 was $73.7 \%$ x $65.1 \%$ in the group of patients treated with cyclosporin, $42.9 \% \times 36.5 \%$ in the group treated with etanercept + MTX, $63.1 \%$ x 79.9\% in the etanercept group, $69.8 \%$ x $93.8 \%$ in the adalimumab group, $39.9 \% \mathrm{x}$ $42.2 \%$ in the MTX group, $44.2 \%$ x $54.8 \%$ in the acitretin group, $88.0 \%$ x $89.6 \%$ in the infliximab + MTX group and $93.9 \%$ x $64.3 \%$. in the ustekinumab group.

Analogic evaluation was performed for BSA at week 12 and at week 24. Cyclosporin group showed a mean decrease in BSA by $81.0 \%$ x $76.0 \%$, etanercept + MTX group by $40.5 \%$ x $44.1 \%$, etanercept group by $54.5 \%$ x $79.4 \%$, adalimumab group by $74.4 \%$ x $95.8 \%$, MTX group by $34.1 \%$ x $36.0 \%$, acitretin group by $31.7 \%$ x $55.1 \%$, infliximab + MTX group by $86.4 \%$ x $89.9 \%$ and ustekinumab group by $93.5 \%$ x $66.0 \%$.

Differences in the decrease of PASI score and BSA index between individual groups evaluated by Kruskal Wallis test were statistically significant (Table 5).

In addition, Mann-Whitney test with Bonferroni correction of significance was used to compare the decrease 
Table 4. Decrease in PASI and BSA values in percentages.

\begin{tabular}{|c|c|c|c|c|c|}
\hline \multicolumn{2}{|c|}{ Medication } & $\begin{array}{l}\text { PASI decrease } \\
\text { at week } 12\end{array}$ & $\begin{array}{l}\text { PASI decrease } \\
\text { at week } 24\end{array}$ & $\begin{array}{l}\text { BSA decrease } \\
\text { at week } 12\end{array}$ & $\begin{array}{l}\text { BSA decrease } \\
\text { at week } 24\end{array}$ \\
\hline \multirow[t]{6}{*}{ MTX } & $\mathrm{N}$ & 16 & 16 & 16 & 16 \\
\hline & Minimum & -85.7 & -100.0 & -88.2 & -100.0 \\
\hline & Maximum & .0 & 6.7 & .0 & .0 \\
\hline & Median & -41.4 & -27.6 & -27.0 & -15.0 \\
\hline & Mean & -39.9 & -42.2 & -34.1 & -36.0 \\
\hline & Std. Deviation & 26.9 & 35.0 & 31.8 & 39.8 \\
\hline \multirow[t]{6}{*}{ Acitretin } & $\mathrm{N}$ & 11 & 11 & 11 & 11 \\
\hline & Minimum & -55.6 & -92.9 & -68.8 & -97.8 \\
\hline & Maximum & -30.8 & -7.4 & .0 & .0 \\
\hline & Median & -42.9 & -60.0 & -34.4 & -66.7 \\
\hline & Mean & -44.2 & -54.8 & -31.7 & -55.1 \\
\hline & Std. Deviation & 7.2 & 28.5 & 25.5 & 36.4 \\
\hline \multirow[t]{6}{*}{ Infliximab + MTX } & $\mathrm{N}$ & 8 & 8 & 8 & 8 \\
\hline & Minimum & -100.0 & -100.0 & -100.0 & -100.0 \\
\hline & Maximum & -70.6 & -72.7 & -57.9 & -63.2 \\
\hline & Median & -92.3 & -91.4 & -89.7 & -94.3 \\
\hline & Mean & -88.0 & -89.6 & -86.4 & -89.9 \\
\hline & Std. Deviation & 11.6 & 8.8 & 15.3 & 12.4 \\
\hline \multirow[t]{6}{*}{ Ustekinumab } & $\mathrm{N}$ & 4 & 4 & 4 & 4 \\
\hline & Minimum & -100.0 & -100.0 & -100.0 & -100.0 \\
\hline & Maximum & -85.4 & -7.3 & -84.6 & -20.0 \\
\hline & Median & -95.1 & -75.0 & -94.7 & -72.0 \\
\hline & Mean & -93.9 & -64.3 & -93.5 & -66.0 \\
\hline & Std. Deviation & 6.1 & 44.7 & 6.5 & 40.5 \\
\hline
\end{tabular}

Report - decrease in \%

in PASI score and BSA index between two groups of patients treated with different preparations (Table 6). Significant differences ( $P$ less than 0.05$)$ are shown in bold. With very small samples, ustekinumab $(n=4)$ and etanercept $+\operatorname{MTX}(n=4)$ the groups were not evaluated.

At week 12, the following was demonstrated by the MannWhitney test:

- significantly greater decrease in PASI score in the group of patients treated with a combination of infliximab + MTX (median - 92\%) compared to the group of patients treated with methotrexate (median - $41 \%$ ), acitretin (median - 43\%) and etanercept (median $57 \%$ ).

- significantly greater decrease in the group of patients treated with etanercept (median - 57\%) compared to the methotrexate group (median - 41\%) and to the acitretin group (median - 43\%).

- significantly greater decrease in the group of patients treated with cyclosporin (median - 76\%) compared to the acitretin group (median $-43 \%$ ).

\section{At week 24, the following was demonstrated:}

- significantly greater decrease in PASI score in the group of patients treated with adalimumab (median $100 \%$ ) compared to the methotrexate group (median $28 \%$ ), acitretin group (median $-60 \%$ ) and cyclosporin group (median - 67\%).

- significantly greater decrease in the group of patients treated with infliximab + MTX (median - 91\%) compared to the cyclosporin group (median - 67\%) and acitretin group (median - 60\%). 
Table 5. Decrease of PASI and BSA (at week 12 and at week 24) evaluated by Kruskal-Wallis test - comparison of individual groups according to medication.

\begin{tabular}{lcccc}
\hline & PASI decrease at week & PASI decrease at week & BSA decrease at week & BSA decrease at week \\
& 12 & 24 & 12 & 24 \\
\hline Chi-Square & 42.110 & 29.485 & 33.988 & 28.886 \\
Df & 7 & 7 & 7 & 4 \\
Asymp. Sig. & 0.0001 & .0001 & $<0.0001$ & .0002 \\
\hline
\end{tabular}

Test Statistics ${ }^{\mathrm{a}, \mathrm{b}}$

a. Kruskal Wallis Test; b. Grouping Variable: medication

Table 6. Comparison of the decrease of PASI score and BSA index between two groups.

\begin{tabular}{lcccc}
\hline & $\begin{array}{c}\text { Decrease of } \\
\text { PASI at week 12 }\end{array}$ & $\begin{array}{c}\text { Decrease of } \\
\text { PASI at week 24 }\end{array}$ & $\begin{array}{c}\text { Decrease of BSA } \\
\text { at week 12 }\end{array}$ & $\begin{array}{c}\text { Decrease of BSA } \\
\text { at week 24 }\end{array}$ \\
\hline Cyclosporin vs. acitretin & $\mathbf{0 . 0 0 7}$ & 1.000 & $\mathbf{0 . 0 2 8}$ & 1.000 \\
Cyclosporin vs. MTX & 0.056 & 1.000 & $\mathbf{0 . 0 4 9}$ & 0.918 \\
Cyclosporin vs. etanercept & 1.000 & 0.086 & 0.649 & 1.000 \\
Cyclosporin vs. adalimumab & 0.776 & $\mathbf{0 . 0 0 1}$ & 1.000 & $\mathbf{0 . 0 3 6}$ \\
Cyclosporin vs. infliximab+MTX & 0.551 & $\mathbf{0 . 0 2 2}$ & 1.000 & 0.314 \\
Acitretin vs. MTX & 1.000 & 1.000 & 1.000 & 1.000 \\
Acitretin vs. etanercept & $\mathbf{0 . 0 0 5}$ & 0.078 & 1.000 & 0.276 \\
Acitretin vs. adalimumab & 0.051 & $\mathbf{0 . 0 3 4}$ & $\mathbf{0 . 0 4 4}$ & $\mathbf{0 . 0 2 5}$ \\
Acitretin vs. infliximab+MTX & $\mathbf{0 . 0 0 4}$ & $\mathbf{0 . 0 3 4}$ & $\mathbf{0 . 0 0 6}$ & 0.176 \\
MTX vs. etanercept & $\mathbf{0 . 0 2 9}$ & $\mathbf{0 . 0 1 7}$ & 0.751 & $\mathbf{0 . 0 1 0}$ \\
MTX vs. adalimumab & 0.353 & $\mathbf{0 . 0 3 8}$ & 0.102 & $\mathbf{0 . 0 2 3}$ \\
MTX vs. infliximab+MTX & $\mathbf{0 . 0 0 9}$ & 0.066 & $\mathbf{0 . 0 0 9}$ & $\mathbf{0 . 0 3 6}$ \\
Etanercept vs. adalimumab & 1.000 & 0.494 & 0.784 & 0.361 \\
Etanercept vs. infliximab+MTX & $\mathbf{0 . 0 2 7}$ & 1.000 & 0.059 & 1.000 \\
Adalimumab vs. infliximab+MTX & 1.000 & 1.000 & 1.000 & 1.000 \\
\hline
\end{tabular}

Significance of the Mann-Whitney test with Bonferroni correction of significance - significant differences $(P<0.05)$ are shown in bold.

- significantly greater decrease in the group of patients treated with etanercept (median - 85\%) compared to the methotrexate group (median - 28\%).

In addition, Mann-Whitney test demonstrated the following at week 12:

- significantly greater decrease in BSA in the group of patients treated with cyclosporin (median - 81\%) compared to the methotrexate group (median - 27\%) and acitretin group (median - 34\%).

- significantly greater decrease in BSA in the group of patients treated with the combination of infliximab + MTX (median - 90\%) compared to the methotrexate group (median - 27\%) and acitretin group (median $34 \%)$.

- significantly greater decrease in BSA in the group of patients treated with adalimumab (median - 83\%) compared to the group of patients treated with acitretin (median - 34\%).
At week 24, the following was demonstrated by the MannWhitney test:

- significantly greater decrease in BSA in the group of patients treated with adalimumab (median - 100\%) compared to the methotrexate group (median - 15\%), acitretin group (median - 67\%) and cyclosporin group (median - 76\%).

- significantly greater decrease in the group of patients receiving a combination of infliximab + MTX (median - 94\%) compared to the group of patients treated with methotrexate (median - 15\%).

- significantly greater decrease in the group of patients treated with etanercept (median - 87\%) compared to the group of patients treated with methotrexate (median - 15\%).

Further, a decrease in PASI score by $75 \%$ or more and decrease in BSA index by $50 \%$ or more were found, both at week 12 and week 24 of treatment (Table 7-10). 
Table 7. Decrease of PASI by 75\% or more at week 12 .

\begin{tabular}{|c|c|c|c|c|}
\hline \multirow{2}{*}{ Medication } & & \multicolumn{2}{|c|}{ PASI decrease at week $12<=75 \%$} & \multirow{2}{*}{ Total } \\
\hline & & no & yes & \\
\hline Cyclosporin & $\begin{array}{c}\text { Count } \\
\%\end{array}$ & $\begin{array}{c}6 \\
50.0 \%\end{array}$ & $\begin{array}{c}6 \\
50.0 \%\end{array}$ & $\begin{array}{c}12 \\
100.0 \%\end{array}$ \\
\hline Etanercept+MTX & $\begin{array}{c}\text { Count } \\
\%\end{array}$ & $\begin{array}{c}4 \\
100.0 \%\end{array}$ & $\begin{array}{c}0 \\
0 \%\end{array}$ & $\begin{array}{c}4 \\
100.0 \%\end{array}$ \\
\hline Etanercept & $\begin{array}{c}\text { Count } \\
\%\end{array}$ & $\begin{array}{c}21 \\
72.4 \%\end{array}$ & $\begin{array}{c}8 \\
27.6 \%\end{array}$ & $\begin{array}{c}29 \\
100.0 \%\end{array}$ \\
\hline Adalimumab & $\begin{array}{c}\text { Count } \\
\%\end{array}$ & $\begin{array}{c}4 \\
44.4 \%\end{array}$ & $\begin{array}{c}5 \\
55.6 \%\end{array}$ & $\begin{array}{c}9 \\
100.0 \%\end{array}$ \\
\hline MTX & $\underset{\%}{\text { Count }}$ & $\begin{array}{c}13 \\
81.3 \%\end{array}$ & $\begin{array}{c}3 \\
18.8 \%\end{array}$ & $\begin{array}{c}16 \\
100.0 \%\end{array}$ \\
\hline Acitretin & $\begin{array}{c}\text { Count } \\
\%\end{array}$ & $\begin{array}{c}11 \\
100.0 \%\end{array}$ & $\begin{array}{c}0 \\
0 \%\end{array}$ & $\begin{array}{c}11 \\
100.0 \%\end{array}$ \\
\hline Infliximab+MTX & $\begin{array}{c}\text { Count } \\
\%\end{array}$ & $\begin{array}{c}2 \\
25.0 \%\end{array}$ & $\begin{array}{c}6 \\
75.0 \%\end{array}$ & $\begin{array}{c}8 \\
100.0 \%\end{array}$ \\
\hline Ustekinumab & $\begin{array}{c}\text { Count } \\
\%\end{array}$ & $\begin{array}{c}0 \\
0 \%\end{array}$ & $\begin{array}{c}4 \\
100.0 \%\end{array}$ & $\begin{array}{c}4 \\
100.0 \%\end{array}$ \\
\hline Total & $\begin{array}{c}\text { Count } \\
\%\end{array}$ & $\begin{array}{c}61 \\
65.6 \%\end{array}$ & $\begin{array}{c}32 \\
34.4 \%\end{array}$ & $\begin{array}{c}93 \\
100.0 \%\end{array}$ \\
\hline
\end{tabular}

Crosstab

\begin{tabular}{ccc}
\hline & Value & $\begin{array}{c}\text { Exact Sig. } \\
\text { (2-sided) }\end{array}$ \\
\hline $\begin{array}{c}\text { Fisher's exact test } \\
\text { N of Valid Cases }\end{array}$ & $\begin{array}{c}17.271 \\
\mathbf{0 . 0 0 2}\end{array}$ \\
\hline Compared groups & \multicolumn{2}{c}{ Significance $^{\mathrm{a}}$} \\
\hline $\begin{array}{c}\text { Acitretin vs. } \\
\text { infliximab+MTX }\end{array}$ & 0.015 \\
\hline
\end{tabular}

Fisher's exact test

${ }^{a}$ significance of the Fisher's exact test with Bonferroni correction

Statistically significant differences in decrease in PASI score were found in week 12 between the group of patients treated with the combination infliximab and MTX compared with the group of patients treated with acitretin $(P=0.015)$, in week 24 between patients treated with etanercept or adalimumab and patients treated with methotrexate ( $P=0.028, P=0.020$ ).

When comparing the decrease in BSA index by $50 \%$ or more at weeks 12 and 24, between individual groups of patients treated with different preparations, Fischer's exact test revealed no significant differences.

In addition, we observed and evaluated the occurrence of any subjective or objective side effects of the administered therapy (Table 11).

Patients treated with biological preparations usually exhibited mild side effects, primarily mild respiratory infections which did not require treatment cessation. Patients treated with etanercept more often exhibited a reaction at the injection site- reddening was observed in four patients. In a few cases, itching and headache were reported at the beginning of therapy. Prolonged withdrawal of etanercept was necessary in one patient due to complicating bronchopneumonia and another patient presented with transient elevated transaminases. Treatment with adalimumab in one patient worsened his herpes zoster and one patient treated with ustekinumab had to postpone dose application by four weeks due to prolonged respiratory infection.

Conventional drugs (cyclosporin, methotrexate, acitretin) were more often poorly tolerated during the course 
Table 8. Decrease of PASI by 75\% or more at week 24 .

\begin{tabular}{|c|c|c|c|c|}
\hline \multirow{2}{*}{\multicolumn{2}{|c|}{ Medication }} & \multicolumn{2}{|c|}{ PASI decrease at week $24<=75 \%$} & \multirow{2}{*}{ Total } \\
\hline & & no & yes & \\
\hline Cyclosporin & $\begin{array}{c}\text { Count } \\
\%\end{array}$ & $\begin{array}{c}6 \\
66.7 \%\end{array}$ & $\begin{array}{c}3 \\
33.3 \%\end{array}$ & $\begin{array}{c}9 \\
100.0 \%\end{array}$ \\
\hline Etanercept+MTX & $\begin{array}{c}\text { Count } \\
\%\end{array}$ & $\begin{array}{c}2 \\
50.0 \%\end{array}$ & $\begin{array}{c}2 \\
50.0 \%\end{array}$ & $\begin{array}{c}4 \\
100.0 \%\end{array}$ \\
\hline Etanercept & $\begin{array}{c}\text { Count } \\
\%\end{array}$ & $\begin{array}{c}7 \\
25.0 \%\end{array}$ & $\begin{array}{c}21 \\
75.0 \%\end{array}$ & $\begin{array}{c}28 \\
100.0 \%\end{array}$ \\
\hline Adalimumab & $\begin{array}{c}\text { Count } \\
\%\end{array}$ & $\begin{array}{c}0 \\
0 \%\end{array}$ & $\begin{array}{c}7 \\
100.0 \%\end{array}$ & $\begin{array}{c}7 \\
100.0 \%\end{array}$ \\
\hline MTX & $\begin{array}{c}\text { Count } \\
\%\end{array}$ & $\begin{array}{c}12 \\
75.0 \%\end{array}$ & $\begin{array}{c}4 \\
25.0 \%\end{array}$ & $\begin{array}{c}16 \\
100.0 \%\end{array}$ \\
\hline Acitretin & $\begin{array}{c}\text { Count } \\
\%\end{array}$ & $\begin{array}{c}8 \\
72.7 \%\end{array}$ & $\begin{array}{c}3 \\
27.3 \%\end{array}$ & $\begin{array}{c}11 \\
100.0 \%\end{array}$ \\
\hline Infliximab+MTX & $\begin{array}{c}\text { Count } \\
\%\end{array}$ & $\begin{array}{c}1 \\
12.5 \%\end{array}$ & $\begin{array}{c}7 \\
87.5 \%\end{array}$ & $\begin{array}{c}8 \\
100.0 \%\end{array}$ \\
\hline Ustekinumab & $\underset{\%}{\text { Count }}$ & $\begin{array}{c}2 \\
50.0 \%\end{array}$ & $\begin{array}{c}2 \\
50.0 \%\end{array}$ & $\begin{array}{c}4 \\
100.0 \%\end{array}$ \\
\hline Total & $\begin{array}{c}\text { Count } \\
\%\end{array}$ & $\begin{array}{c}38 \\
43.7 \%\end{array}$ & $\begin{array}{c}49 \\
56.3 \%\end{array}$ & $\begin{array}{c}87 \\
100.0 \%\end{array}$ \\
\hline
\end{tabular}

Crosstab

\begin{tabular}{lcc}
\hline & Value & $\begin{array}{c}\text { Exact Sig. } \\
\text { (2-sided) }\end{array}$ \\
\hline $\begin{array}{l}\text { Fisher's exact test } \\
\mathrm{N} \text { of Valid Cases }\end{array}$ & $\begin{array}{c}22.442 \\
\text { Compared groups }\end{array}$ & 0.0001 \\
\hline Etanercept vs. MTX & Significance $^{\mathrm{a}}$ \\
\hline Adalimumab vs. MTX & $\mathbf{0 . 0 2 8}$ \\
\hline
\end{tabular}

Fisher's exact test

a significance of the Fisher's exact test with Bonferroni correction

of treatment with a number of subjective side effects at normally administered doses and often doses needed to be reduced with subsequent failure of therapeutic effect.

In patients treated with cyclosporin, side effects consisted mainly of fatigue, sweating and tremor; two patients exhibited severe headaches and nausea. Objective side effects during cyclosporine therapy were the development of hypertension in three patients, two patients demonstrated elevated serum lipid levels and one patient developed gingivitis. After six months of cyclosporine therapy, one patient was diagnosed with breast cancer upon screening mammogram and treatment had to be terminated.

During the course of treatement with methotrexate, three cases of digestive problems were reported- nausea and vomiting and one patient reported severe fatigue and weakness. Objective symptoms included diffuse alopecia in one patient, two patients had elevated liver enzymes and two cases exhibited myelosuppression with development of leucopenia and anemia.

In patients treated with acitretin, the frequency of mild as well severe side effects was most pronounced and was exhibited by 11 of 13 patients treated with this preparation. Most patients reported severe and bothersome mucosal dryness. Four patients developed drug-induced hepatopathy and required immediate therapy withdrawal. Two patients exhibited significant elevation of serum lipid levels.

Twelve patients treated with combination therapy (infliximab+MTX, etanercept+MTX) presented with mild side effects; two patients treated with the combination etanercept + methotrexate had mild respiratory infections and one patient treated with the combination infliximab + methotrexate reported nausea, which ceased after reducing the dose of MTX. Methotrexate doses in combination therapy with infliximab and etanercept were at the lower end of the dosing scheme (5-7.5mg 1x weekly) when compared to MTX monotherapy.

Differences in occurrence of side effects associated with type of systemic therapy are summarized in Table 12. 
Table 9. Decrease of BSA by 50\% or more at week 12 .

\begin{tabular}{|c|c|c|c|c|}
\hline \multirow{2}{*}{ Medication } & & \multicolumn{2}{|c|}{ BSA decrease at week $12<=50 \%$} & \multirow{2}{*}{ Total } \\
\hline & & no & yes & \\
\hline Cyclosporin & $\begin{array}{l}\text { Count } \\
\%\end{array}$ & $\begin{array}{c}2 \\
16.7 \%\end{array}$ & $\begin{array}{c}10 \\
83.3 \%\end{array}$ & $\begin{array}{c}12 \\
100.0 \%\end{array}$ \\
\hline Etanercept+MTX & $\begin{array}{l}\text { Count } \\
\%\end{array}$ & $\begin{array}{c}2 \\
50.0 \%\end{array}$ & $\begin{array}{c}2 \\
50.0 \%\end{array}$ & $\begin{array}{c}4 \\
100.0 \%\end{array}$ \\
\hline Etanercept & $\begin{array}{l}\text { Count } \\
\%\end{array}$ & $\begin{array}{c}15 \\
51.7 \%\end{array}$ & $\begin{array}{c}14 \\
48.3 \%\end{array}$ & $\begin{array}{c}29 \\
100.0 \%\end{array}$ \\
\hline Adalimumab & $\begin{array}{l}\text { Count } \\
\%\end{array}$ & $\begin{array}{c}1 \\
11.1 \%\end{array}$ & $\begin{array}{c}8 \\
88.9 \%\end{array}$ & $\begin{array}{c}9 \\
100.0 \%\end{array}$ \\
\hline MTX & $\begin{array}{l}\text { Count } \\
\%\end{array}$ & $\begin{array}{c}9 \\
56.3 \%\end{array}$ & $\begin{array}{c}7 \\
43.8 \%\end{array}$ & $\begin{array}{c}16 \\
100.0 \%\end{array}$ \\
\hline Acitretin & $\begin{array}{l}\text { Count } \\
\%\end{array}$ & $\begin{array}{c}7 \\
63.6 \%\end{array}$ & $\begin{array}{c}4 \\
36.4 \%\end{array}$ & $\begin{array}{c}11 \\
100.0 \%\end{array}$ \\
\hline Infliximab+MTX & $\begin{array}{l}\text { Count } \\
\%\end{array}$ & $\begin{array}{c}0 \\
0 \%\end{array}$ & $\begin{array}{c}8 \\
100.0 \%\end{array}$ & $\begin{array}{c}8 \\
100.0 \%\end{array}$ \\
\hline Ustekinumab & $\begin{array}{l}\text { Count } \\
\%\end{array}$ & $\begin{array}{c}0 \\
0 \%\end{array}$ & $\begin{array}{c}4 \\
100.0 \%\end{array}$ & $\begin{array}{c}4 \\
100.0 \%\end{array}$ \\
\hline Total & $\begin{array}{l}\text { Count } \\
\%\end{array}$ & $\begin{array}{c}36 \\
38.7 \%\end{array}$ & $\begin{array}{c}57 \\
61.3 \%\end{array}$ & $\begin{array}{c}93 \\
100.0 \%\end{array}$ \\
\hline
\end{tabular}

Crosstab

\begin{tabular}{lcc}
\hline & Value & $\begin{array}{c}\text { Exact Sig. } \\
(2 \text {-sided })\end{array}$ \\
\hline Fisher's exact test & 17.247 & $\mathbf{0 . 0 0 3}$ \\
N of Valid Cases & 85 & \\
\hline
\end{tabular}

Fisher's exact test

When compared with biological therapy $(36.4 \%)$ or combined therapy $(25.0 \%)$ conventional therapy exhibited a significantly higher occurrence of side effects $(69.8 \%)$, $P=0.008$ resp. $P=0.023$.

\section{DISCUSSION}

In the last few years, progress in research of the pathogenesis of psoriasis has led to the introduction of new therapeutic methods, particularly in severe forms of this disease. New preparations from the group of selective immunosuppressants have significantly altered the prognosis and quality of life of these patients. The products, also referred to as biologics, were also introduced into the therapy of other immune-mediated disorders with pathogenesis in many aspects similar to psoriasis ${ }^{2,18-21}$. In our country, approach to systemic therapy changed following the publication of guidelines for the biological treatment of psoriasis by the Czech Dermatological Society in 2006 (ref. ${ }^{9}$ ). These guidelines were based on recommendations of major national societies.

These measures led to a significant improvement in the quality of life of patients and allowed many of them to return to normal life ${ }^{13,22-25}$.

The paper presents an assessment of our own experience with individual methods of systemic treatment of psoriasis in patients who were subject to clinical and laboratory follow-up in the specialized Counseling Centre at the Department of Dermatology for at least 24 weeks.

One of the main criteria was to assess the effectiveness of individual therapeutic methods, measured by a standard expression of the percentage of patients who achieved PASI 75 and BSA 50 at monitored intervals. At the same time, average decrease in PASI score and BSA index were evaluated at weeks 12 and 24 of treatment in individual groups. The highest decrease was observed during treatment with the monoclonal antibody infliximab (in combination with low-dose MTX) and adalimumab. Somewhat lower (but still highly significant) reduction 
Table 10. Decrease of BSA by $50 \%$ or more at week 24 .

\begin{tabular}{|c|c|c|c|c|}
\hline \multirow{2}{*}{ Medication } & & \multicolumn{2}{|c|}{ BSA decrease at week $24<=50 \%$} & \multirow{2}{*}{ Total } \\
\hline & & no & yes & \\
\hline Cyclosporin & $\begin{array}{l}\text { Count } \\
\%\end{array}$ & $\begin{array}{c}1 \\
11.1 \%\end{array}$ & $\begin{array}{c}8 \\
88.9 \%\end{array}$ & $\begin{array}{c}9 \\
100.0 \%\end{array}$ \\
\hline Etanercept+MTX & $\begin{array}{l}\text { Count } \\
\%\end{array}$ & $\begin{array}{c}2 \\
50.0 \%\end{array}$ & $\begin{array}{c}2 \\
50.0 \%\end{array}$ & $\begin{array}{c}4 \\
100.0 \%\end{array}$ \\
\hline Etanercept & $\begin{array}{l}\text { Count } \\
\%\end{array}$ & $\begin{array}{c}4 \\
14.3 \%\end{array}$ & $\begin{array}{c}24 \\
85.7 \%\end{array}$ & $\begin{array}{c}28 \\
100.0 \%\end{array}$ \\
\hline Adalimumab & $\begin{array}{l}\text { Count } \\
\%\end{array}$ & $\begin{array}{c}0 \\
0 \%\end{array}$ & $\begin{array}{c}7 \\
100.0 \%\end{array}$ & $\begin{array}{c}7 \\
100.0 \%\end{array}$ \\
\hline MTX & $\begin{array}{l}\text { Count } \\
\%\end{array}$ & $\begin{array}{c}10 \\
62.5 \%\end{array}$ & $\begin{array}{c}6 \\
37.5 \%\end{array}$ & $\begin{array}{c}16 \\
100.0 \%\end{array}$ \\
\hline Acitretin & $\begin{array}{l}\text { Count } \\
\%\end{array}$ & $\begin{array}{c}4 \\
36.4 \%\end{array}$ & $\begin{array}{c}7 \\
63.6 \%\end{array}$ & $\begin{array}{c}11 \\
100.0 \%\end{array}$ \\
\hline Infliximab+MTX & $\begin{array}{l}\text { Count } \\
\%\end{array}$ & $\begin{array}{c}0 \\
0 \%\end{array}$ & $\begin{array}{c}8 \\
100.0 \%\end{array}$ & $\begin{array}{c}8 \\
100.0 \%\end{array}$ \\
\hline Ustekinumab & $\begin{array}{l}\text { Count } \\
\%\end{array}$ & $\begin{array}{c}2 \\
50.0 \%\end{array}$ & $\begin{array}{c}2 \\
50.0 \%\end{array}$ & $\begin{array}{c}4 \\
100.0 \%\end{array}$ \\
\hline Total & $\begin{array}{l}\text { Count } \\
\%\end{array}$ & $\begin{array}{c}23 \\
26.4 \%\end{array}$ & $\begin{array}{c}64 \\
73.6 \%\end{array}$ & $\begin{array}{c}87 \\
100.0 \%\end{array}$ \\
\hline
\end{tabular}

Crosstab

\begin{tabular}{lcc}
\hline & Value & $\begin{array}{c}\text { Exact Sig. } \\
\text { (2-sided) }\end{array}$ \\
\hline Fisher's exact test & 17.778 & $\mathbf{0 . 0 0 1}$ \\
N of Valid Cases & 79 & \\
\hline
\end{tabular}

Fisher's exact test

was observed during treatment with etanercept. Against expectations, the average decrease was lower in patients treated with ustekinumab and the combination of etanercept and MTX. However, the number of treated patients was small which could affect the results, as well as the previous treatment of some patients with efalizumab and its forced withdrawal after the registration of the product, followed by a "rebound phenomenon" (ref. ${ }^{26}$ ). In correlation with the results of larger studies, a faster (when compared to soluble receptor etanercept) onset of action of monoclonal antibodies infliximab and adalimumab was found ${ }^{3,10-12,14}$.

At week 12, cyclosporin was the conventional medication with significantly highest efficacy. Its effect however significantly decreased at week 24. Compared to other groups, lower efficacy of MTX and acitretin was observed at both treatment intervals, which is surprising, especially for MTX as this is usually reported to have higher efficiency $^{11,27,28}$.

Analysis of the decrease in PASI score by $75 \%$ and BSA by $50 \%$ in individual groups shows fewer significant differences. It indicates greater efficacy of biologicals compared to conventional therapies. In accordance with the literature, the gradual onset of etanercept, which reached its maximum after several months, when it approached the therapeutic effect of monoclonal antibodies, was confirmed ${ }^{5,29,30}$.

The efficacy of treatment with conventional prepara-

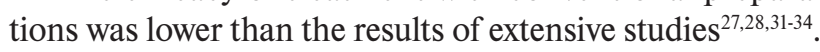
This was clearly caused by a frequent occurrence of side effects, which rendered it impossible for a large number of patients to maintain an optimal therapeutic dose in the long term. With the reduction of dose, side effects partially subsided, but at the same time there was a pronounced decrease of therapeutic effect, especially in patients treated with cyclosporin.

Biologicals caused only mild side effects, which usually did not require dose reduction and the therapeutic effect was therefore not affected by the above mechanism. 
Table 11. Occurrence of side effects during treatment by individual preparations, in \%.

\begin{tabular}{|c|c|c|c|c|c|}
\hline \multirow{2}{*}{ Medication } & & & \multicolumn{2}{|c|}{ Occurrence of side effects } & \multirow{2}{*}{ Total } \\
\hline & & & No & Yes & \\
\hline & \multirow[t]{2}{*}{ cyclosporin } & Count & 3 & 10 & 13 \\
\hline & & $\%$ & $23.1 \%$ & $76.9 \%$ & $100.0 \%$ \\
\hline & \multirow[t]{2}{*}{ etanercept+MTX } & Count & 2 & 2 & 4 \\
\hline & & $\%$ & $50.0 \%$ & $50.0 \%$ & $100.0 \%$ \\
\hline & \multirow[t]{2}{*}{ etanercept } & Count & 18 & 11 & 29 \\
\hline & & $\%$ & $63.6 \%$ & $36.4 \%$ & $100.0 \%$ \\
\hline & \multirow[t]{2}{*}{ adalimumab } & Count & 7 & 4 & 11 \\
\hline & & $\%$ & $63.6 \%$ & $36.4 \%$ & $100.0 \%$ \\
\hline & \multirow[t]{2}{*}{ MTX } & Count & 8 & 9 & 17 \\
\hline & & $\%$ & $47.1 \%$ & $52.9 \%$ & $100.0 \%$ \\
\hline & \multirow[t]{2}{*}{ acitretin } & Count & 2 & 11 & 13 \\
\hline & & $\%$ & $15.4 \%$ & $84.6 \%$ & $100.0 \%$ \\
\hline & \multirow[t]{2}{*}{ infliximab+MTX } & Count & 7 & 1 & 8 \\
\hline & & $\%$ & $87.5 \%$ & $12.5 \%$ & $100.0 \%$ \\
\hline & \multirow[t]{2}{*}{ ustekinumab } & Count & 3 & 1 & 4 \\
\hline & & $\%$ & $75.0 \%$ & $25.0 \%$ & $100.0 \%$ \\
\hline \multirow{2}{*}{\multicolumn{2}{|c|}{ Total }} & Count & 50 & 49 & 99 \\
\hline & & $\%$ & $50.5 \%$ & $49.5 \%$ & $100.0 \%$ \\
\hline
\end{tabular}

Crosstabulation

Table 12. Contingency table- comparison of occurrence of side effects in the group of conventional preparations (cyclosporin, methotrexate, acitretin), biological preparations (etanercept, adalimumab, ustekinumab) and combined therapy (infliximab + MTX, etanercept + MTX).

\begin{tabular}{|c|c|c|c|c|c|}
\hline \multirow{2}{*}{ Therapy } & & & \multicolumn{2}{|c|}{ Occurence of side effects } & \multirow[t]{2}{*}{ Total } \\
\hline & & & No & Yes & \\
\hline & \multirow[t]{2}{*}{ biological } & Count & 28 & 16 & 44 \\
\hline & & \%within therapy & $63.6 \%$ & $36.4 \%$ & $100.0 \%$ \\
\hline & \multirow[t]{2}{*}{ combined } & Count & 9 & 3 & 12 \\
\hline & & \%within therapy & $75.0 \%$ & $25.0 \%$ & $100.0 \%$ \\
\hline & \multirow[t]{2}{*}{ conventional } & Count & 13 & 30 & 43 \\
\hline & & \%within therapy & $30.2 \%$ & $69.8 \%$ & $100.0 \%$ \\
\hline \multirow{2}{*}{ Total } & & Count & 50 & 49 & 99 \\
\hline & & $\%$ within therapy & $50.5 \%$ & $49.5 \%$ & $100.0 \%$ \\
\hline
\end{tabular}

Crosstabulation

\begin{tabular}{lc}
\hline & $P$ (Fisher's exact test) \\
\hline Conventional vs. biological & $\mathbf{0 . 0 0 8}$ \\
Conventional vs. combined & $\mathbf{0 . 0 2 3}$ \\
Biological vs. combined & 1.000 \\
\hline
\end{tabular}

Significance of Fischer's exact test with Bonferroni correction 


\section{CONCLUSION}

Our own experience with the systemic treatment of psoriasis can be summarized as:

Treatment with biological preparations is more effective than conventional medicines.

Conventional therapy is often limited by serious side effects which require dosage reduction or discontinuation of treatment.

In addition to improved efficacy, biologicals are welltolerated. Over several months of therapy, side-effects were less frequent and less serious.

No greater efficacy of the combined therapy with etanercept + MTX compared to etanercept alone was demonstrated.

The advantages of infliximab combination with low-dose MTX in the prophylaxis of allergic reactions described during treatment with infliximab alone were verified. No allergic reaction was observed during treatment with this combination.

\section{CONFLICT OF INTEREST STATEMENT}

Author's conflict of interest diclosure: None of the authors has any proprietary interest.

\section{REFERENCES}

1. Tichý $M$, Ditrichová $D$. Biologicals in the treatment of severe forms of psoriasis. Dermatol praxi 2007;1:19-21.

2. Tichý M, Ditrichová D. Biological treatment in dermatology. Klin Farmakol Farm 2008;22(2):68-71.

3. Bachmann F, Nast A, Sterry W, Philipp S. Safety and efficacy of the tumor necrosis factor antagonists. Semin Cutan Med Surg 2010;29(1):35-47. Review.

4. Kurzeja M, Rudnicka L, Olszewska M. New interleukin - 23 pathway inhibitors in dermatology: ustekinumab, briakinumab and secukinumab. Am J Clin Dermatol 2011;12(2):113-25.

5. van de Kerkhof PCM, Segaert S, Lahfa M, Luger TA, Karolyi Z, Kaszuba Z, Leigheb G, Camacho FM, Forsea D, Zang C, Boussuge MP, Paolozzi L, Wajdula J. One weekly administration of etanercept $50 \mathrm{mg}$ is efficacious and well tolerated in patients with moderate-to-severe plaque psoriasis: a randomized controlled trial with open-label extension. Br J Dermatol 2008;159:1177-85.

6. Leonardi C, Papp K, Strober B, Reich K, Asahina A, Gu Y, Beason J, Rozzo S, Tyring S. The long-term safety of adalimumab treatment in moderate to severe psoriasis: a comprehensive analysis of all adalimumab exposure in all clinical trials. Am J Clin Dermato 2011;12(5):321-37.

7. Hoffmann $\mathrm{JH}$, Hartmann M, Enk AH, Hadaschik EN. Autoantibodies in psoriasis as predictors for loss - of - response and anti - infliximab antibody induction. Br J Dermatol (Epub ahead of print).

8. Lebwohl M, Leonardi C, Griffiths CE, Prinz JC, Szapary PO, Yeilding N, Guzzo C, Li S, Hsu MC, Strober B. Long-term safety experience of ustekinumab in patients with moderate - to - severe psoriasis (Part I of II): Results from analyse of general safety from pooled Phase 2 and 3 clinical trials. J Am Acad Dermatol 2011 (Epud ahead of print).

9. Benáková N, Štork J. Treatment of Psoriasis with Biologicals. Consensual Guidelines of The Czech Dermatovenereological Society of the CMA JEP 2006. Čes Slov Derm 2006;81(4):S1-11.

10. Smith $\mathrm{CH}$, Anstey AV, Barker JN, Burden AD, Chalmers RJG, Chandler DA, Finlay AY, Griffiths CEM, Jackson K, McHugh NJ, McKenna KE, Reynolds NJ, Ormerod AD. British Association of Dermatologists guidelines for biologic interventions for psoriasis 2009. Br J Dermatol 2009;161(5):987-1019.

11. Pathirana D, Ormerod AD, Saiag P, Smith C, Spuls PI, Nast A, Barker J, Bos JD, Burmester GR, Chimenti S, Dubertret R, Eberlein B, Erdmann R, Ferguson J, Girolomoni G, Gisondi P, Giunta A, Griffiths $C$, Hönigsmann $H$, Hussain $M$, Jobling $R$, Karvonen SR, Kemeny $L$, Kopp I, Leonardi C, Maccarone M, Menter A, Mrowietz U, Naldi L, Nijsten T, Ortonne JP, Orzechowski HD, Rantanen T, Reich K, Reytan N, Richards H, Thio HB, Van de Kerkhof P, Rzany B. European S3Guidelines on systemic treatment of psoriasis vulgaris. J Eur Acad Dermatol Venereol 2009;23(suppl. 2):1-70.

12. Papp K, Gulliver W, Lynde C, Poulin Y, Ashkenas J, Canadian Psoriasis Guidelines Committee. Canadian giudelines for the management of plaque psoriasis: overview. J Cutan Med Surg 2011;15(4):192-200.

13. Mrowietz U, Kragballe $K$, Reich $K$, Spuls $P$, Griffiths $C E$, Nast A, Franke J, Antoniou C, Arenberger P, Balieva F, Bylaite M, Correia O, Daudén E, Gisondi P, Iversen L, Kemény L, Lahfa M, Nijsten T, Rantanen T, Reich K, Rosenbach T, Segaert S, Smith C, Talme T, Volc-Platzer B, Yawalkar N. Definition of treatment goals for moderate to severe psoriasis: a European consensus. Arch Dermatol Res 2011;303(1):1-10.

14. American Academy of Dermatology Work Group, Menter A, Korman NJ, Elmets CA, Feldman SR, Gelfand JM, Gordon KB, Gottlieb A, Koo JY, Lebwohl M, Leonardi CL, Lim HW, Van Voorhees AS, Beutner KR, Ryan C, Bhushan R. Guidelines of care for the management of psoriasis and psoriatic arthritis: section 6. Guidelines of care for the treatment of psoriasis and psoriatic arthritis: case-based presentations and evidence-based conclusions. J Am Acad Dermatol 2011;65(1):137-74. Review.

15. Ettler K. Indexy v klinickém hodnocení psoriázy a atopického ekzému. Čes-slov Derm 1995;70(1):45-7.

16. Benáková N, Ettler K, Štork J, Vašků V. Psoriáza nejen pro praxi, Praha: Triton; 2007,164 s.

17. Garduno J, Bhosle MJ, Balkrishnan R, Feldman SR. Measures used in specifying psoriasis lesion(s), global disease and quality of life: a systematic review. J Dermatol Treat 2007;18:223-42.

18. Griffiths $C E$, Barker JN. Pathogenesis and clinical features of psoriasis. Lancet 2007;370:263-71.

19. Christophers E. Comorbidities in psoriasis. J Eur Acad Dermatol Venereol 2006;20:52-5.

20. Krueger JG, Bowcock A. Psoriasis pathophysiology: current concept of pathogenesis. Ann Rheum Dis 2005;64:30-6.

21. Vašků V. Comorbidities in psoriasis - a new perspective of an old disease. Dermatol praxi 2009;3(2):63-6.

22. Revicki D, Willian MK, Saurat JH, Papp KA, Ortonne JP, Sexton C, Camez A. Impact of adalimumab treatment on health-related quality of life and other patient-reported outcomes: results from a 16-week randomized controlled trial in patients with moderate to severe plaque psoriasis. Br J Dermatol 2008;158:549-57.

23. Reich K, Nestle FO, Papp K, Ortonne JP, Wu Y, Bala M, Evans R, Guzzo C, Li S, Dooley LT, Griffiths CE. Improvement in quality of life with infliximab induction and maintenance therapy in patients with moderate-to-severe psoriasis: a randomized controlled trial. $\mathrm{Br} J$ Dermatol 2006;154:1161-8

24. Tyring S, Gottlieb A, Papp K, Gordon K, Leonardi C, Wang A, Lalla D, Woolley M, Jahreis A, Zitnik R, Cella D, Krishnan R. Etanercept and clinical outcomes, fatigue, and depression in psoriasis: double-blind placebo-controlled randomised phase III trial. Lancet 2006;367:2935.

25. Krishnan R, Cella D, Leonardi C, Papp K, Gottlieb AB, Dunn M, Chiou $C F$, Patel $V$, Jahreis $A$. Effects of etanercept therapy on fatigue and symptoms of depression in subjects treated for moderate to severe plaque psoriasis for up to 96 weeks. Br J Dermatol 2007;157:1275-7.

26. Menter A, Hamilton TK, Toth DP, Leung HM, Wetherill G, Hennessey B, Garovoy M, Kwon P, Pariser DM. Transitioning patients from efalizumab to alternative psoriasis therapies: findings from an openlabel, multicenter, phase III study. Int J Dermatol 2007;46:637-48.

27. Smith KC. Systemic therapy of psoriasis using methotrexate. Skin Therapy Lett 2000;6:1-2;5.

28. Strober BE, Siu K, Menon K. Conventional systemic agents for psoriasis. A systematic review. J Rheumatol 2006;33:1442-6.

29. Giannetti A. Commentary on the European S3- Guidelines on the systemic treatment of Psoriasis. J Eur Acad Dermatol Venereol 2010;24:p.368. 
30. Tichý M, Ditrichová D. Commentary to the Guidelines of The European Dermatology Forum on the Systemic Treatment of Psoriasis Vulgaris. Čes-slov Derm 2010;85(4):215-8.

31. Menter A, Griffiths CE. Current and future management of psoriasis. Lancet 2007;370:272-84.

32. Smith $\mathrm{CH}$, Barker JNWN. Psoriasis and its management. BMJ 2006;333:380-4.
33. Koo J. A randomized, double-blind study comparing the efficacy, safety and optimal dose of two formulations of cyclosporin, Neoral and Sandimmun, in patients with severe psoriasis. OLP302 Study Group. Br J Dermatol 1998;139:88-95.

34. Murray HE, Anhalt AW, Lessard R, Schacter RK, Ross BJ, Stewart WD, Geiger JM. A 12-month treatment of severe psoriasis with acitretin: results of a Canadian open multicenter study. J Am Acad Dematol 1991;24:598-602. 